\title{
EUROPE, IDEA OF A CONTINENT: THE QUEST FOR THE EUROPEAN IDENTITY
}

\author{
Koo van der Wal \\ Department of Philosophy, \\ Erasmus University Rotterdam, \\ PO Box 1738, 3000 Dr Rotterdam \\ E-mail: koo.v.d.wal@planet.nl
}

\begin{abstract}
Against a widespread scepticism with regard to the existence of a European identity, the article maintains both that there is such a thing as European culture and mentality or European "story", and that there has to be one, if European economy, law and politics are to be successful in the longer run. The article attempts to show ideal-typically that there is quite a series of interconnected common features (institutions, practices, convictions and guiding ideas) on the European continent. This can also be made visible in the contrast with non-western cultures, and within the western cultural area with the American society and mentality as well. It is not denied that the European "story" is often distorted by a stubborn reality (power relations, conflicts of interests, etc.). Nevertheless, it is constantly working on all levels of the European society and offers guidance to the processes at work there.
\end{abstract}

Keywords: cultural factor, democracy, European "story", no-demos argument, differentiation of society.

DOI: $10.3846 / 2029-0187.2008 .1 .148-159$

\section{Europe, an ongoing debate}

Europe continues to occupy our minds. To give some examples: in 2004 the cultural think tank Nexus organised a series of conferences in the Hague, Warsaw, Berlin and even Washington D.C. where intellectuals, researchers, politicians and jurists discussed the question of the European identity and of the route ahead Europe should take. Still, more well-known is the series of conferences for the end of framing the European constitution. Understandably this process and subsequently the plebiscite on the constitution in various countries were accompanied by a flood of publications. The same was (and is) the case with the topic of the expansion of the European Union. And those debates are, obviously because of the importance of the matter, not at all an inner-European concern only. Americans, Russians and a lot of others contributed to these discussions ${ }^{1}$ as well. So in point of fact, Europe is keeping the minds of many persons busy.

The embarrassing thing with that is that the contributions operate at very different levels and from very different perspectives. For some, like the former Dutch member of the European Commission Bolkestein, Europe is primarily, and in fact solely, an economic project. In this view the main role of the Union is the completion of the internal market.

1 See, e.g., the article "The door does not need to be opened to Turkey and the Ukraine" by Russian political scientist and economist Vladislav Inozemtsev in the Dutch newspaper Trouw (02-05-2006). 
However, the economy is never only economy. It always functions within wider juridical, political, social and cultural contexts, that is within whole a set of non-economic preconditions, such as trust, sense of duty, integrity of rulers, managers and public servants, political and social stability, a certain work ethics, a well-functioning legal system, a good educational system and several other factors. And not in the last place, the economy functions within a context of shared convictions, values and fundamental attitudes which are characteristic of a particular society. So whoever pursues an economic policy necessarily pursues a juridical, educational, social etc. policy, all of this against the background of more general cultural and ideal matters of fact (which for their part, if only indirectly, also are affected in that way).

In that manner Europe has meanwhile developed a whole corpus of European public and civil law with the corresponding institutions and organs. Likewise on the European level policies are pursued with respect to education, police cooperation, environment, etc. In short, whoever pursues economic policies is always doing more, viz. is implementing a specific (maybe largely implicit) view of society and of the human identity. And the more the processes on the European level are moving forward, having passed the stage of limited practical arrangements, the more that view of society and identity (who we are, and especially who we want to be, in this part of the world) becomes ever more important.

So the question is: what is Europe, what is the matter the name refers to? Probably, Europe has never been the name solely of a continent in a purely geographic sense. Put otherwise, social and historical connotations were implied in the notion from the start. That becomes visible already from the fact that Europe, as it does not have clear natural borders at the Eastern side at any rate, is no clearly demarcated entity from a geographic viewpoint. So, historical and religious-cultural factors were involved in its delineation as long as Europe has existed. Although in this way Europe was always more than a geographic concept, this surely is the case today, now that all kinds of integration processes (in the monetary, agricultural, legal field, etc.) are at work. Since all sorts of phenomena have gone sailing under European colours (European law, the European Court of Human Rights, Europol, Euratom, etc. ${ }^{2}$ ), Europe consequently has become ever more important to life on the continent ${ }^{3}$. And so the question of the European identity gains an ever increasing urgency. It is from that perspective that attempts should be seen to frame a European constitution, a document, that is to say, intending to give a profile and blueprint of the social-political entity Europe.

For a long time hardly any attention was paid to that question. And the urgency for that was not felt seriously. I already touched upon that above, because mostly, e.g. with regard to monetary or agricultural policies, very practical questions were at stake, which moreover concerned only a specific sector of society and therefore hardly brought into vision Europe as a more encompassing unit. And still it cannot be denied

2 One could mention further, among other things: the European Central Bank, the European Parliament, the European Social Charter (1961), all kinds of European policies (agricultural etc.), the European Environmental Agency, Eurotransplant, but also European Cup football, the Eurovision Song Contest, etc.

3 For instance: European law takes precedence over national law, at any rate in the Netherlands, but not (automatically) in Germany. 
that the factors spurring the European unification process are to a considerable extent of a practical-pragmatic kind, such as the necessity of a common security and environmental policy, but first of all the pressure to be able, in a globalising economy, to carry on the race, especially with America and Japan, but also with rising powers such as China, India, Brazil and others.

\section{The importance of the cultural factor}

But it is questionable whether that is the whole story. Could it be so - a question I will try to answer (rather roughly) affirmatively in the following - that all these practical processes and initiatives suppose a frame of orientation that ultimately directs them and make them possible? That, in other words, I already alluded to that above, all these processes rest on a "cultural" basis, or have a cultural dimension which, however, often (or should one say: usually?) is ignored. This claim is connected with two other ones.

Firstly, that a community is more than the sum total of its parts, that is that it constitutes a communal unit that transcends its components; and secondly, that goal-oriented action presupposes, however implicitly, a more or less intact frame of orientation. I explain this in a little more detail. With regard to the first claim: as one of the characteristics of modern society the differentiation of society is often mentioned, i.e. the gaining of relative autonomy of sectors like economy, law, science, art etc. They are, in other words, considered to answer to their own specific norms and to function according to their own laws only. In that manner science and politics emancipate themselves from religion, economy sets itself free from morality and politics, law is considered as an independent closed domain with its own idiom, logic and procedures, and in art only aesthetic criteria are deemed valid, and so on.

The German sociologist Niklas Luhmann can be considered as one of the most marked representatives of this differentiation thesis (see, e.g., Luhmann 1990). He describes the modernization process as the development from a stratificatory to a functionally differentiated society. In this view "society" is nothing but an umbrella term of self-referential functional systems of which each possesses an operational autonomy as they function according to their own binary code (science of true and false, the law of just and unjust, etc.). They only observe one another from their own frame of reference, influence the functioning of one another only in a derivative sense, and react mainly to internal disturbances and not directly to the environment of the system. For Luhmann in this way all social subsystems are quasi-autonomous. Something like an underlying unity of the subsystems, or a life world that encompasses separate sectors of society, is totally out of question.

Undoubtedly differentiation is an important characteristic of modernity. And it is the source of important achievements, as well (for that matter) of weighty problems, of the modern age. But views such as Luhmann's seem to me to offer a strong misrepresentation of the modern situation because they overrate the self-sufficiency of the "subsystems" and in that way reduce society to the sum total of its constituents. It may be that certain sectors of society like science, technology and economy are able to 
a higher degree, than other ones, to determine the conditions of their functioning and that they do convey the impression that their development mainly displays dynamics of their own. But surely that does not apply to all sectors of society and probably to none in the full sense.

To give some examples: no doubt the law has a "technicity" of its own, i.e. a specific idiom, logic and procedures, which are often still hardly accessible for a layman and therefore require a special expertise. In contrast with that in olden times in Israel the firstborn passed sentence guided by a sense of justice that was rooted in the community's tradition and sharpened by experience of life. And in Athens it belonged to the civic prerogatives to be allowed to participate in the administration of justice. But although modern law has become "technical" and a matter of experts, that is not and cannot be the whole story. If the law is not to a sufficient degree in keeping with the citizens' sense of justice, it loses its legitimacy and, together with that, its binding power. The development of the law remains to a high degree under the influence of everyday convictions living in the community. From its very nature the law can only to a certain extent define its points of departure and basic assumptions. To that extent the dynamics of the law is not so much a matter of the law itself, but is determined by external factors. The law, in short, is to an important degree the expression of the symbolic universe of the community in general, of the prevailing view of man and society, such as, that in principle people are of equal standing in front of the law (so class justice is out of the question) or, on the contrary, are of unequal standing as in feudal societies; that men and women are equal or just have different social roles, duties and rights; that people cannot be the object of property and cannot be sold etc., as is the case in societies practising slavery; that torture and cruel corporal punishment are permitted or not, etc.

An analogous story applies for the economy, to return for a moment to a subject I already touched upon earlier, although it is considered rather generally as an independent sector of society - in my view a typically modern-western idiosyncracy, and a disastrous one at that. It is for that matter already a curious thing that the independence of the economy rests on political decisions of liberalizing and deregulating it. We set, in other words, the economy free because of the modern belief that it constitutes the key to human well-being. But beside that, particularly in the field of development aid, it dawned on us that the economy always functions within broader political, social and cultural contexts. Development of "less developed" societies turned out, otherwise than people thought around 1960, not to be solely a matter of injecting capital and technology (of course, that is implied as well), but first of all to be a comprehensive political, social and cultural process. Just because, as I said above, the economy always functions within a broader framework of society as a whole, or, put otherwise, functions by the grace of the availability of a whole range of conditions of a non-economic kind, such as political stability, trust of the population in the social process etc.

But if the functioning of the economy depends upon a whole series of factors of a political, social and cultural kind, then there exist at least as many forms of economy as there are different political, social and cultural systems or life-styles. In other words, there cannot be one general economic model, unless it is imposed from the outside and, then, almost inevitably leads to derailment. What now generally passes for economy is 
thus the economic expression of the western type of society with its scanty and superficial social relations, its stress because of high workload and sharp competitiveness, and its definition of well-being in terms of material welfare and its chronic neglect of the immaterial dimensions of well-being.

Similar stories could be told with regard to literature, art, sports, and even science and technology. The thesis is, in short, that each society gets the economy, legal system, literature, art, science etc. it "deserves", i.e. which are the expression of the outlook and mentality that prevail in that society. Applied to Europe, it means that here as well such a common outlook and mentality has to be presumed in the background of the practical processes. They should then be made explicit, because it is to be expected that, especially where more fundamental decisions are concerned, they will come into play. Long drawnout conflicts could then turn out to be caused beside by clashes of interest, by differences of interpretation of those background convictions or by a lack of such a basic consensus. In that case something like a European community would consequently be a fiction.

\section{A background of shared values}

With regard to the second claim stated above, that practical processes rest upon a "cultural" foundation, yet another consideration points in the same direction. Where practical questions are concerned, as in the case of monetary, agricultural, environmental or security policies, what actually (at any rate mostly) is at stake is a matter of problem solving, i.e. finding adequate answers to practical problems. Put otherwise: what is at stake is goal-rational action, to use Max Weber's expression. Insofar politics confines itself to that, i.e. takes goals more or less for granted and now looks for the most appropriate strategies and means to achieve them, it constitutes (or, in this case, degenerates into) a form of social technology.

But goals presuppose, however implicitly, convictions about what is of value. Now, with regard to values three statements can be made: (a) They have to be made explicit to gain clarity about what one wants more precisely; and not in the last place to have an insight into where different values clash, what one therefore cannot want at the same time, and how and with what implications values can be accommodated; (b) To be really able to motivate people, values have to be articulated and made experientially recognisable, and their embodiment in attitudes, practices, institutions and life-styles has to be made clear; (c) Values do not float around separately in the world, but they are bound up with views about reality, man and society. In that sense values have an ontological (and epistemological) dimension which has to be made visible in the process of making them explicit. For instance, the modern idea of freedom is connected with an individualism (often conceived in an atomic fashion) in the contemplation of man. Also it implies an emancipation of a man from nature, and correlates in connection with that with an objectivistic and "disenchanted" image of nature (see Thomas Hobbes, Immanuel Kant and Jean Paul Sartre, among others).

In short, values are situated in the context of a more encompassing frame of reference, in which, as has been said, the ontological, axiological and epistemological dimensions are interwoven with each other and mutually refer to each other. 
Once again applied to Europe this means that goal-rational action on the European level presupposes a framework of orientation guiding that action - or in case of absence frustrating it, at least in the long run. Put otherwise: the European associations directed to a specific purpose require, to be able to function enduringly, an underlying community and culture, or a European "story" and outlook that is lived in practice. Regularly, in this connection the term "community of values" is used. Then, evidently, what has just been said about values applies, viz. that they always are situated within broader frames of reference. And the question is, of course: does that story or that community (of outlook, values and life) exist, and if so, to what extent and in what fashion?

There is a lot of scepsis with regard to this, and not altogether without grounds. In Europe, so the argument runs, the disparity in thinking, ways of life and mentality is too great to allow it to be considered as a community of life, whereas furthermore the inhabitants of the continent hardly possess a feeling of solidarity towards one another - the well-known no-demos argument. Behind this phrasing lie hidden, as is clear, the features characterising a nation, i.e. a group of people united by objective and subjective factors: as to the former (objective) features by a common territory, a common history, language, culture, way of life and the like, and as to the latter (subjective) ones by a feeling of oneness and solidarity. Tested by these criteria, thus (this line of argument continues), Europe is no demos, no community that can form the basis of European political unity other than a federation of sovereign states.

Now, it is possible to raise the question whether there has to be a demos before, and on the basis of which, a political unity can come into being. Most existent political communities were put together "top-down" by means of conquest, inheritance, marriage and suchlike, and after that became a nation little by little (Great Britain, Germany, France, Spain, the Netherlands and so on; and still the traces of these previously independent components have not disappeared totally; think, for instance, of Scotland, "Freistaat Bayern", Catalonia, among many other examples). But such a process of nation-building that would be started top-down is out of question in modern Europe, determined as it is by the idea of democracy and popular sovereignty.

According to some authors, among others Habermas, a demos is not needed at all. In a debate with Dieter Grimm, Habermas states (Habermas 1995) that democracy does not rest upon an underlying national or ethnic unity. On the contrary, he says, it is the result of an abstract solidarity between strangers that is framed by laws. In the case of Europe that solidarity, then, has to be a cross-border one. That seems to me, however, to be a much too narrow notion of democracy, and one that will not work at that. Such a solidarity that is based on abstract principles only, simply will not take root because it has no experiential value and motivating power. Let me deal with the matter in a little more detail.

\section{The idea of democracy}

Surely, democracy not infrequently is conceived of, as to its nature, as a system of political decision-making, as a matter, that is, of procedures and institutional arrangements, in the first place majority rule. If that is the whole story, democracy is, therefore, a purely formal matter, viz. an aggregate of rules of play by means of which the political decision-making 
process is regulated as to its form, without any implication with respect to its content. This conception of democracy is, however, to my mind insufficient to render a satisfactory account of at least the western views and intuitions regarding democracy ${ }^{4}$. Mostly we associate a number of things with the idea of democracy which are not in the least purely formal and normatively neutral, but which denote an ideal of living together and in that sense possess a clearly normative connotation, such as freedom, equality of all in their quality as human beings, implying for instance equality of all before the law, tolerance and respect with regard to one another's convictions and ways of life, protection of minorities and safeguarding of human rights.

As a consequence, democracy is not at all a matter solely of abstract principles and institutional arrangements. It is the expression on the political level of a free, open and "anti-authoritarian" form of life more in general that is also practised in companies, schools, families, all kinds of associations, etc. In short, beside a formal institutional framework of political decision-making, democracy is first of all the idea of a social-political order with an accompanying image of man and fundamental attitudes ${ }^{5}$. As a political institution it is based on a supra-political idea or "story" that is typical of all relationships.

\section{Basic idea and components of the European "story"}

The core of that idea or story is respect for the human person as a being with insight, experience, conscience and will of its own, a being who because of those qualities has to be taken seriously and given the opportunity to determine his own identity and way of life. Attitudes which fit in with this basic idea are self-criticism and, as already mentioned, tolerance and respect (within certain limits) regarding other ways of giving shape to one's own identity. Where this image of man and these basic attitudes have developed not at all or only weakly, where the institution of democracy is not backed by a story like this and an accompanying network of practices and attitudes, there, as history shows, it soon withers away or gets perverted by alien patterns of behaviour like abuse of power, intimidation and corruption.

If, that is the implication of the above, Europe is to be more than a series of practical arrangements and associations directed to specific objectives - in the long run that would be a dead end - then there has to be a story that is characteristic of the European identity, or an organizing idea or cluster of ideas, naturally together with the accompanying attitudes and practices. In short, there has to be a European culture and mentality. And the question is: does it exist? I think it does, becoming particularly visible in the contrast with non-western (African, Asian etc.) cultures, and within the western cultural area also with the American society and mentality.

To underpin that statement I list a series of components of the (modern) European story: besides the already mentioned democracy, understood in its broad "cultural"sense,

4 That is the subject I am talking about in this connection. For other conceptions of democracy, see e.g. Macpherson 1965.

5 Cf. Sartori 1968: 112: "The term democracy indicates both a set of ideals and a political system < .. >", to which he adds a bit further that the idea of democracy "is a by-product of the entire development of Western civilisation". 
the constitutional state with its rule of law, the idea of human rights, a humane criminal law with its guarantees of a fair trial, the equality of all citizens (in the sense of being entitled to an equal respect irrespective of race, religion or philosophy of life, gender or sexual inclination), "bottom up" legitimation in politics, organizations etc. which furthermore is not automatically connected with specific positions in society, but has to be "deserved" by the persons holding those positions by means of an authority creating behaviour. Underlying all these things ultimately is the same organizing idea (or complex of ideas), viz. respect for the person as a being in its own right, i.e. the person herself is the instance to give shape to her own life and identity. From this point of view she has to be offered full scope to develop her personality according to her own convictions, naturally under the condition that it does not compromise the opportunity of her fellow-men to do the same. To formulate the matter otherwise: those profound convictions, often designated as "convictions of conscience", which are of overriding importance to the person in question and shape her identity, call upon society and the fellow citizens to respect them (and the lines of conduct immediately connected with them ${ }^{6}$ ) - not because of the content of those convictions which may be pretty bizarre, but out of respect for the person holding them. Analogously, in the case of the freedom of religion not the content of whatever religion is at stake, but the person expressing $\mathrm{him} /$ herself in it, who in that way asks for respect for a fundamental expression of her identity. That is: with the freedom of religion it is not so much religion or a particular religion as such that is the subject of protection, but the religious person or group of persons.

All things mentioned above (democracy, the constitutional state, respect for other people's deep-seated convictions, etc.) revolve around the same normative idea of humanity, in the inter-human relationships in general, but particularly in politics. Put differently, in all kinds of contexts a basic idea expresses itself anew, viz. that people are primarily the subject of their own lives and are the ones to give them a personal interpretation. Or, as a well-known phrasing runs: that people are always treated also as an end in themselves and never simply as a pure means or object without a will of their own. Implications, among others, are: anti-paternalism, minimizing asymmetrical power relations and replacing them by legal and symmetrical communicative relationships.

Not in the last place the purport of the above-mentioned basic idea can be made visible from the contrast. It excludes practices such as slavery, human trafficking, degrading and unworthy treatment e.g. of prisoners, detention without charge, torture, cruel punishment, kidnapping, taking of hostages - in short, all kinds of actions by which people are treated purely as objects; and further things like dictatorship, oligarchy, intimidation, blood feud, "honour killings", i.e. the practice of avenging someone's (e.g. your sister's) honour, etc.

It is, to give still one further example, not difficult to see that human rights rest upon the afore-mentioned organizing idea, therefore play such a prominent role in European thinking, and that the separate human rights form the materialization more in detail of that idea. Human rights can be understood as public guarantees for the development of citizens as persons. Whatever human rights may be beside that - the question then is, for instance, whether they have a so-called "horizontal working", i.e. whether they also have

6 Such as conscientious objection to military service, to vaccination, etc. 
currency in the relations among citizens and among private bodies like corporations - human rights are primarily the principles of political ethics, prompted by a supra-political idea. Once again: it is the tenor of human rights to create conditions on the political level of society for the development of being human as a person and subject.

\section{Distinctive features vis-à-vis America}

I said above that the European "story", the existence of which, I hope, may have become plausible in the foregoing, makes visible the specific character of a European identity not only vis-à-vis non-western cultural spheres, but inside western culture also vis-à-vis America. This could be elucidated in the following way: The motto of the French Revolution "Liberty, equality and fraternity" can be considered as one of the condensed wordings of the European basic idea. It maintains, by the way, a narrow relationship to the idea of human rights. Not by chance was the first action of the French National Assembly in 1789 the drafting of the Declaration of the Rights of Man and of Citizens, which was meant as the ideal foundation upon which the new social and political order was to be raised. In other words, the idea of human rights and the motto of the French Revolution mutually refer to one another.

Now, the American bills of rights, as the Virginia Bill and the Declaration of Independence of 1776, overlap to a considerable extent with the French Declaration and the motto of the Revolution, except in one respect: the neglect of the theme of fraternity ${ }^{7}$. Consequently, in the view of the framers of the Constitution, the French society is not based only on liberty and equality, or, as one could say, on equal liberty - there ends the matter in America - but beside that on solidarity. Not coincidentally in Europe the constitutional state developed into the social constitutional state or welfare state ("sozialer Rechtsstaat", as the Germans call it). By European standards the freedom of the citizens cannot be guaranteed sufficiently solely by the means of negative rights (rights of non-interference), but it requires also the creation of positive guarantees in the form of facilities in the fields of education, health care, provisions for old age, unemployment compensations, etc. Therefore, although possibly the welfare state has to be restructured because it has gone awry, yet I think that the connection of equal liberty and solidarity, as it was first given expression in the motto of the French Revolution, is a fundamental characteristic of Europe and cannot be abandoned. A chilly and hard society à la America, in short, is un-European.

To illustrate this disparity with regard to the social climate and mentality, one could point to the difference between the American and the European ("Rhineland") business model. The former is highly competitive and result-oriented, and first of all pays attention to the organisation structure (over against the organisation culture) of the companies. What is at stake in this respect, as is well-known, are matters as the organisation as an impersonal

7 American, or more broadly "Anglo-Saxon", social and political philosophers sometimes are aware of this. See e.g., Rawls 1971: 105, where he remarks that "in comparison with liberty and equality, the idea of fraternity has had a lesser place in democratic theory". And in the Afterword of his book Lukes 1973: 158, Steven Lukes writes that the analysis or "map" he has given of the concept of individualism "focuses on liberty and equality, but ignores the crucial third term of fraternity, or community". 
network of functions, formal lines of decision authority, "human resource management", "targets", "output" and suchlike. With this go standoffish and cool inter-human contacts which see and treat people only as occupants of certain positions. From this perspective little attention is paid to the organisational culture, i.e. to the importance of factors such as the atmosphere of the unit or company where one works, interest in one another's personal circumstances, team spirit and mutual trust, engagement and positive identification of the workers with the company.

Interesting in this connection is the opinion of Donald Kalf in his book Independence for Europe. The End of the American Business Model ${ }^{8}$. Kalf's thesis is that the hard American model causes ever higher social costs which for a long time have remained rather invisible, such as tensions between business branches (e.g. corporations and the financial circuit), between different management sections within the company, etc; but first of all, that the American model, due to the fact that it parasitizes on all sorts of social resources but at the same time erodes them, seriously has undermined the social foundations of cooperation, trust and commitment. In other words, that model constitutes an assault on crucial conditions for a good and enduring functioning of corporations. In Kalf's opinion, and rightly so to my mind, the European or "Rhineland" model, more than the rough American model, has an eye for these social resources or for the human and personal aspect of the business world, and therefore has better prospects, at least in the long run.

\section{Philosophical underpinnings}

Philosophically this whole train of thought, emphasizing the importance of social and inter-human aspects of human life, is also more in line with the views that in the last century have been developed by the so-called dialogical and hermeneutic philosophies and then were adopted by other schools of thought. From the perspective of those philosophies man is not by nature the solitary, pre-social individual of early-modern social and political philosophy who only secondarily enters into social relationships. Seen that way, society is entirely a goal-oriented association that has been established by means of a contract. So, from this point of view social relations are (nothing but) contractual relations ${ }^{9}$, and society is simply the aggregate of the individuals concerned - the corollary of that is, of course, that the common good equals the sum total of the private interests. Over against this ontological individualism, which, as indicated, views the mutually independent individuals as the last real building blocks of society, for which in this way the subject is a substance category ${ }^{10}$ and relations are of a purely external kind, that is, irrelevant to the identity of the persons concerned, the above-mentioned philosophies take the view that man from his very nature is a community- and communication-oriented being. In other words, man as a person realizes himself in and through the relationships he is involved

\footnotetext{
8 Original title in Dutch: Kalf 2004.

9 See e.g. Gauthier 1977. The first sentence of the article reads: "The conception of social relationships as contractual lies at the core of our ideology."

10 Think of Descartes' designation of the subject or ego as a "thinking thing” (res cogitans).
} 
in. So relations in this manner are crucial factors in the shaping of his identity as a human person. They affect him to the core of his nature - not all of course, some remaining external and superficial, but many do. The person, that is to say, is a relation category rather than a substance category. Here also lies the reason that man from his very nature is a social and cultural being living in a communal context with its symbolic universe, way of life, language and tradition, outside which he cannot live a fully human life.

\section{Conclusions}

The above is an attempt to explicate ideal-typically the "story" by which European institutions and practices orient themselves. - Once more: there can be no vital institution without supporting story. In the field of religious studies, e.g., it is common knowledge that the rite and the myth are two sides of the same coin, that therefore a rite without its accompanying myth has no chance of survival, at any rate not in the longer run. - But not only is the above sketch of the basic purport of a series of phenomena that are characteristic of Europe ideal-typical, it is also, at least partially, counterfactual: the European social and political reality is determined to a not unimportant extent by non-ideal factors (power relations, conflicts of interests, differences which have arisen and become esta-blished in the course of history, etc.), which are not infrequently at odds with the ideal story. Being impressed by that stubborn reality is in all likelihood the cause of most scepticism regarding Europe.

Nevertheless, however distorted by that stubborn reality, the European story is constantly working on all levels of European society and offers guidance to the processes at work there. Put otherwise: the ideal story continually 'shines through' our acting and thinking. We therefore endorse it performatively and at least implicitly all the time. The philosophical contribution to that could be to articulate and think through the story as broadly as possible and in that way to propound an inspiring and motivating social, cultural and political ideal.

\section{References}

Gauthier, D. 1977. “The Social Contract as Ideology”, Philosophy and Public Affairs 6(2): 130-164.

Habermas, J. 1995. “Comment on the Papet by Dieter Grimm: Does Europe Need a Constitution?”, European Law Journal 1(3): 303-307.

Kalf, D. 2004. Onafhankelijkheid voor Europa. Het einde van het Amerikaanse ondernemingsmodel. Amsterdam, Antwerpen: Business Contact.

Luhmann, N. 1990. Paradigm Lost. Über die ethische Reflexion der Moral. Frankfurt: Suhrkamp.

Lukes, S. 1973. Individualism. Oxford: Oxford University Press.

Macpherson, C. B. 1965. The Real World of Democracy. Toronto: CBC.

Rawls, J. 1971. A Theory of Justice. Cambridge, Mass.: Harvard University Press.

Sartori, G. 1968. International Encyclopedia of the Social Sciences. New York:

Cambridge University Press. 


\title{
EUROPOS KONTINENTO IDE்JA: EUROPIETIŠKOSIOS TAPATYBĖS PAIEŠKOS
}

\author{
Koo van der Wal
}

\begin{abstract}
Santrauka
Atsitolinama nuo plačiai paplitusio skepticizmo ir laikomasi pagarbios pozicijos europietiškosios tapatybės atžvilgiu. Tvirtinama, kad egzistuoja tiek europietiškoji kultūra ir mentalitetas kaip tam tikras europietiškasis „,pasakojimas“, tiek Europos ekonomika, teise ir politika. Bandoma parodyti, kad šiuolaikinėje Europoje gali būti aptinkama gana daug tam tikru glaudžiai susijusių institucijų, veiklos rūšiu, isitikinimu ir vyraujančių idejju. Tai siekiama išryškinti, europietiškają kultūrą supriešinant su nevakarietiškosiomis bei su Amerikos visuomene ir mentalitetu. Straipsnio autoriaus manymu, europietiškasis „pasakojimas“ nūdienëje epochoje neretai vis dar iškraipomas sustabarejusiu galios santykių ir interesų konfliktų, todèl turi būti iš naujo apmąstomas ir interpretuojamas šiuolaikinio socialinio bei filosofinio mąstymo perspektyvoje.
\end{abstract}

Reikšminiai žodžiai: kultūrinis veiksnys, demokratija, europietiškasis ,pasakojimas“, ne-demoso argumentas, visuomenès diferenciacija. 